\title{
Strategic Environmental Assessment of the Territory as a Public Management Instruments for Technological Development. A Case of Ukraine
}

\author{
Mykola MYKOLAICHUK*
}

\begin{abstract}
Faculty of Public Management and Administration, Odesa Regional Institute for Public Administration of the National Academy for Public Administration under the President of Ukraine, Odesa, 65009, Ukraine
\end{abstract}

\begin{abstract}
The study aims to substantiate theoretical and methodological aspects of the use of strategic environmental assessment as an instrument for public regulation of the ecological status of territories. The research methodology is based on using a systematic approach for conducting a strategic environmental assessment of the possibility of environmental problems and threats posed by the implementation of long-term projects and current activities. The development of ecological balance, comparison of the results of normative and exploratory forecasts of the state of the environment become the basis for the formation of goals of strategic environmental management, the appearance of a set of measures for the conservation and restoration of natural resources. Identification of factors influencing the state of the environment is a necessary condition for the prevention of pollution of territories, inefficient use of natural resources, justification of the essential measures of state regulation to ensure the achievement of goals. The practical experience of assessing the achievements in the management of the conditions of the environment is illustrated by the example of regions of Ukraine. The proposed approach to the development of the ecological balance and the methodology of complex assessment of the ecological status of the territory have scientific novelty and contribute to the assessment of the effectiveness of public administration balanced development of the territories.
\end{abstract}

Keywords - Condition of the environment; instruments of influence; management efficiency; public regulation

\section{INTRODUCTION}

Ensuring sustainable development of the territory requires overcoming the contradictions between socio-economic growth and the conservation of natural resources for future generations [1]. However, for vast territories with multinational populations (like Ukraine), regions make a significant contribution to sustainable development. The level of environmental pollution, the state of conservation of biological diversity, the comfort of living, the life expectancy of the population and the level of its well-being depend on the efficiency of management in a particular territory. Therefore, regional sustainable development processes must be managed, and the environmental aspects of strategic

\footnotetext{
*Corresponding author.

E-mail address: mykolaychuk@oridu.odessa.ua 
management should be reflected in predicting the environmental impact of management decisions at any level of government.

An important instrument of public regulation should be a perfect system of evaluation of achievements, which will identify the weaknesses of each component of the socio-economic system and form effective mechanisms of motivation for development. Unfortunately, a sufficiently consistent system of sustainable development indicators for the regions is still lacking even at the international level. The most common methodologies for determining world rankings are the Human Development Index (HDI) and the annual Global Competitiveness Reports, which use two complementary approaches. Still, none of them provides a comprehensive description of the components of sustainable development.

The publications of modern scientists mainly reveal the main problems and factors of macroeconomic growth, substantiate the need for structural adjustment, improvement of fiscal policy, a strategy of foreign economic activity of the country [2]-[5]. The state's strategy to reduce the impact on the health of the environment causes the need to focus on environmental and economic problems, the rational use of natural resources, and providing conditions for the existence of future generations through environmental restoration.

Although each country chooses its path of development and uses models that fit its strategy, global economic trends must be considered. And it is characterized by globalization, which leads to the interdependence of transport, marketing, communications and economic networks of different countries, environmental impact. Therefore, managerial thinking cannot be confined to local interests and conditions; managers need to think in global categories. This approach increases the responsibility for the environmental impact of neighbouring regions and states on a particular territory.

Environmental problems that significantly affect the fate of mankind tend to attract his or her attention when the negative consequences become threatening, and to eliminate them is already very difficult. Therefore, the global community has launched a Strategic Environmental Assessment (SEA). In 2001, 'Directive 2001/42 / EU on the assessment of the effects of individual plans and programmes on the environment' was adopted. Following this, the SEA became mandatory for EU countries. But more and more countries are joining this initiative. At the beginning of 2010, there were already about 60 countries in the world $[1],[6]$.

EU countries at the legislative level confirm the implementation of SEA principles (laws, regulations or regulations, sections in the environmental code, etc.) [7].

Ukraine has also become involved in the process of SEA implementation. This fact is confirmed by the signing of the Protocol on Strategic Environmental Assessment to the Convention on Environmental Impact Assessment in a Transboundary Context and its Ratification in 2015 at the 5th European Conference of Ministers of the Environment 'Environment for Europe' (Kyiv, 2003). The main provisions were reflected in the Law of Ukraine 'On Strategic Environmental Assessment' No. 2354-VIII of 20.03.2018 [8], [9].

The experience of conducting SEO is reflected in numerous publications. A guide has been published providing information on the use of SEA in different countries and industries [10]. Ukraine publishes reports on the SEA of Strategies for the Development of Regions, Cities, and Projects [11]-[13].

The implementation of the SEA draft plans and programs involves the preparation of an environmental report on the possible ecological implications of their application. The public, representatives of environmental authorities, are involved in its discussion. When plans are approved at the initial stage of implementation, unforeseen impacts are monitored [14]. 
Undoubtedly, conducting a SEA is an essential step in addressing environmental concerns. However, the evaluation of individual projects is not enough. The systematic using of SEA in managing the state of the environment is necessary, as the effects of the actions of even one person can be detrimental to the environment. That is why the purpose of this research is substantiating theoretical and methodological aspects of the using of SEA as a tool for public regulation of the ecological conditions of territories. In order to achieve this goal, it is necessary to form indicators of the desired ecological status for a particular stage of territorial development based on the coordinated use of regulatory and search forecasts. The cumulative environmental impact of different activities must be reflected in the ecological balance of the area. It is advisable to develop a methodology for assessing the ecological component of the indicator of sustainable development of the territory. Further, the factors that influence the selected indicators at different levels of government and the degree of their dependence on the activities of public authorities need to be identified. It is crucial to justify the levers of environmental factors.

\section{TheORETICAL ANd Methodological BASES For USING OF STRATEgiC EnVironmental ASSESSMENT in EnVironmental Management}

Based on the report of the World Commission on Environment and Development in 1987, environmental management is one of the three components of managing the sustainable development of a territory [1].

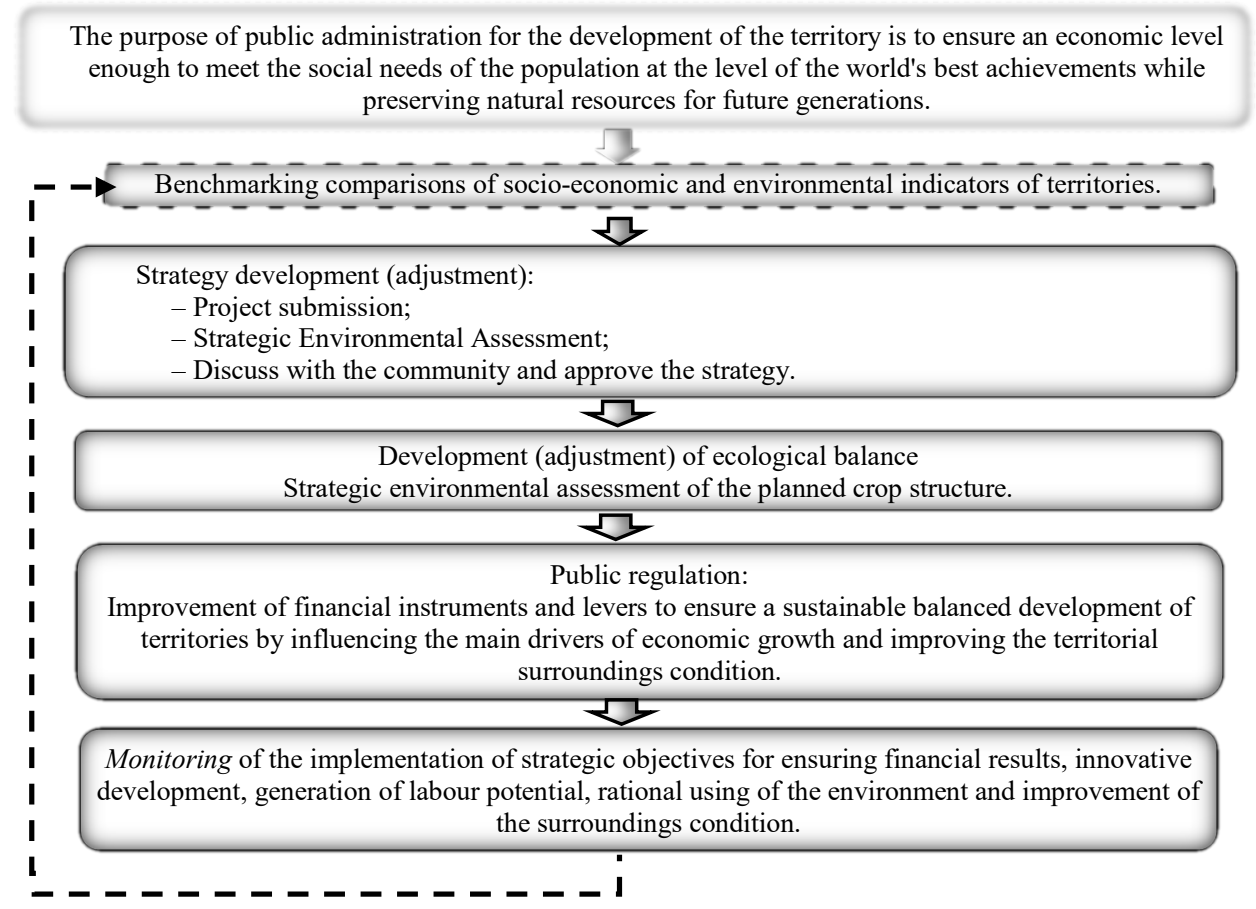

Fig. 1. Strategic environmental assessment in the process of ensuring balanced and sustainable development of a territory. 
The essence of sustainable and balanced development is the application of bifurcation growth mechanisms to ensure profound change and an optimal blend of major factors of production; preservation of natural resource potential, integrity of the state, social guarantees to all sections of the population; creation of conditions for intellectual take-off, development of human capital throughout Ukraine [13].

Ensuring the sustainable development of each region requires the identification of significant environmental problems, possible areas and consequences of economic activity (primarily financial) and providing a balance between economic and ecological goals. Although, economic development allows you to invest in the preservation and restoration of the environment, education, health care and the creation of comfortable living conditions. The goal for ensuring a sustainable and balanced development of the region requires solving some problems related to the formation of an information base to enable benchmarking to compare key development results of regions, oblasts, enterprises and organizations; improving methods for developing a coherent system of strategic plans using strategic environmental assessment; formation of a network of balanced indicators for the structural units of the region; implementation of public regulation of regional development.

The main stages of forming a system for ensuring sustainable and balanced development of the region using SEA are presented in Fig. 1.

For balanced socio-economic development, taking into account the need to preserve and restore the ecosystem, it is advisable to accompany the event of a regional development strategy with the development of an eco-balance that will determine the ecosystem load due to economic activity to ensure human development and the necessary therapeutic measures. The scheme of its construction is presented in Fig. 2.

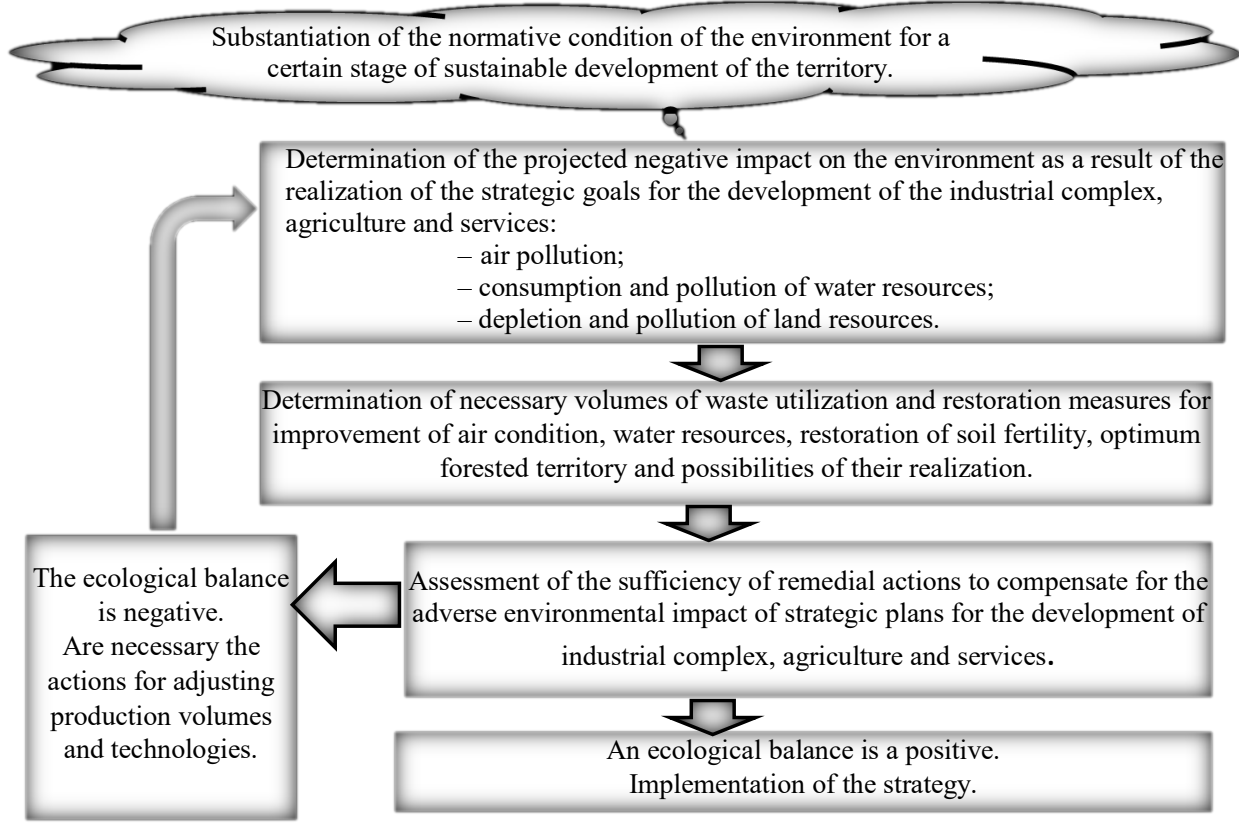

Fig. 2. Scheme of checking of ecological balance during strategy implementation. 
Based on the strategic goals of human development, the necessary volumes of industrial production and services are determined, the environmental consequences of economic activity and interaction of the population and tourists with the environment, the essential measures and volumes of works for the restoration of natural resources and waste management.

Achievements in environmental aspects of sustainable development should be reflected in an appropriate indicator, which, based on a comparative assessment of the territorial indicators of their pollution and the efficiency of the use of natural resources, reveals positive and negative trends in environmental management. Factors for influencing key metrics and levers to adjust them must be identified. It is also advisable to justify the criteria for evaluating the effectiveness of public regulation.

However, favouring environmental issues and preserving natural resources can lead to a new extreme and the loss of past positive developments in the technocracy. There is also the threat of ignoring political, cultural, religious, regional interests, the existence of a significant disparity between the living conditions and the well-being of the population of cities and rural areas. Therefore, there is a growing need for strengthening the regulatory function of the public administration in the implementation of transformation processes in order to realize the concept of sustainable, balanced development.

\section{Methods for Evaluating AChievements in the Management of EnVironmental Protection of Territories}

Studying the most appropriate methodology for evaluating regional level achievements in environmental management should be considered the most effective tool for assessing is a benchmarking comparison of accomplishments in order to develop goals and identify the reserves for future development [2], [3], [7].

It is necessary to avoid ambiguity of interpretations of the concept 'index', which in Ukrainian statistics is defined as the ratio of absolute values and has certain peculiarities for determining the average and the general level, and in English means 'mark'. For this purpose, we propose to call the useful measure of sustainable development and its components as 'indicator'.

To calculate indicator values, we will use the ratio between the value of the measure being analysed and the maximum amount of the mark for regions with stimulus indicators (those that have a positive upward trend),

$$
I_{j}=\frac{x_{j}}{x_{\max }},
$$

and the ratio between the minimum value of the score for the areas and the measure that analysed for indicators - distillers (those that have a negative upward trend).

$$
I_{j}=\frac{x_{\min }}{x_{j}} .
$$

In the case where the minimum value of the analysed index is zero, we will apply Eq. (3).

$$
I_{j}=\frac{x_{\max }-x_{j}}{x_{\max }}
$$


$2021 / 25$

We believe that this approach, which was used in the first method of calculating the Human Development Index, the proposed by Program of the United Nations Development Program (UNDP) in 1990, provides a more 'contrast' characteristics than the formula, where the indicator value is determined as the ratio of the difference between the value of the analysed indicator for a particular region and the maximum amount of this mark in Ukraine to the magnitude of variation of the analysed index.

The environmental management performance indicator should be consistent with the ecological component of the overall sustainability indicator. However, it is essential to pay more attention to the conservation of natural resources to manage the environment. Therefore, it is advisable to characterize the depletion and restoration of these resources instead of indicators of resource efficiency in terms of achieving the highest financial result from land use, industrial use of forest and water resources.

The environmental management performance Indicator ( $\left.I_{\mathrm{EMP}}\right)$ will have the following structure:

$$
I_{\mathrm{EMP}}=0.5 I_{\text {pollut }}+0.5 I_{\text {balance }} .
$$

The first component reflects the improvement (deterioration) of the ecological status of the region in comparison with the others due to the indicators of the discharge of polluted return water $\left(I_{\mathrm{prw}}\right)$, the emission of harmful substances into the air $\left(I_{\mathrm{ehsa}}\right)$, the formation of toxic waste $\left(I_{\mathrm{ftw}}\right)$

$$
I_{\text {pollut }}=0.3 I_{\text {prw }}+0.3 I_{\text {ehsa }}+0.4 I_{\text {ftw }}
$$

An analysis of the results of the calculations given in Table 1 gives grounds for the following conclusions. Only four administrative-territorial regions have less than the average level of pollution in Ukraine (they are marked in grey). Dnipropetrovsk and Donetsk oblasts take the lowest rating position because they have indicators below the national average for all components. Zaporizhzhya and Lviv oblasts have two indicators below the national average: the discharge of polluted return water and the emission of harmful substances into the air. In the regions with one of the indicators below the average level, the Kherson region has ranked in the top ten of the overall pollution prevention rating.

The second component of the Environmental Management Performance Indicator should characterize the balance of consumption of core resources. Loss of soil quality, quantity and quality of water resources and forests should be compensated for through rational use and restoration.

$$
I_{\text {balance }}=0.25 I_{\text {land_bal }}+0.35 I_{\text {forest_bal }}+0.4 I_{\text {water_bal }}
$$

The least weight of the agricultural land resource balance indicator ( $\left.I_{\text {land_bal }}\right)$ is due to the country high level of security and quality characteristics. Agricultural land in Ukraine covers 41.5 million hectares, which is approximately $70.0 \%$ of the whole country. The arable land is 32.5 million hectares (of which almost $50.0 \%$ is black earth). The availability of agricultural land to the population of Ukraine is highest among European countries. Each citizen of Ukraine accounts for 0.9 ha of agricultural land (including arable land $-0.7 \mathrm{ha}$ ), with only 0.44 and 0.25 ha, respectively, in the European average [16], [17]. 
Table 1. The Results of CAlculating the EnVIRONMENTAl Management PeRformance INDICATOR FOR REGIONS OF UKRAINE

\begin{tabular}{llllll}
\hline Region (Oblast) & $\boldsymbol{I}_{\text {prw }}$ & $\boldsymbol{I}_{\text {ehsa }}$ & $\boldsymbol{I}_{\mathbf{f t w}}$ & $\boldsymbol{I}_{\text {pollut }}$ & Rating \\
\hline Chernivtsi & 0.993 & 0.970 & 1.000 & 0.989 & 1 \\
Zakarpattya & 0.986 & 1.000 & 0.083 & 0.629 & 2 \\
Volyn & 1.000 & 0.627 & 0.111 & 0.533 & 3 \\
Rivne & 0.986 & 0.333 & 0.167 & 0.462 & 4 \\
Zhytomyr & 0.993 & 0.311 & 0.100 & 0.431 & 5 \\
Kherson & 0.996 & 0.333 & 0.004 & 0.400 & 6 \\
Ternopil & 0.989 & 0.302 & 0.008 & 0.391 & 7 \\
Kirovohrad & 0.996 & 0.262 & 0.016 & 0.384 & 8 \\
Cherkasy & 0.986 & 0.066 & 0.167 & 0.382 & 9 \\
Chernihiv & 0.951 & 0.101 & 0.143 & 0.373 & 10 \\
Vinnytsya & 0.996 & 0.021 & 0.143 & 0.362 & 11 \\
Khmelnytskiy & 0.996 & 0.152 & 0.029 & 0.356 & 12 \\
Mykolayiv & 0.923 & 0.225 & 0.006 & 0.347 & 13 \\
Kyiv & 0.993 & 0.066 & 0.014 & 0.323 & 14 \\
Sumy & 0.919 & 0.158 & 0.001 & 0.323 & 15 \\
Poltava & 0.993 & 0.057 & 0.001 & 0.316 & 16 \\
Odesa & 0.884 & 0.108 & 0.038 & 0.313 & 17 \\
Kharkiv & 0.965 & 0.071 & 0.002 & 0.312 & 18 \\
Ivano-Frankivsk & 0.996 & 0.016 & 0.014 & 0.310 & 19 \\
Luhansk & 0.937 & 0.043 & 0.016 & 0.300 & 20 \\
Lviv & 0.750 & 0.029 & 0.038 & 0.249 & 21 \\
Zaporizhzhya & 0.775 & 0.018 & 0.006 & 0.240 & 22 \\
Donetsk & 0.296 & 0.004 & 0.001 & 0.090 & 23 \\
Dnipropetrovsk & 0.190 & 0.005 & 0.002 & 0.059 & 24 \\
\hline Average & 0.860 & 0.031 & 0.004 & 0.269 & \\
\hline Dancalch & & & &
\end{tabular}

Data calculated from [15]

The forest resource indicator $\left(I_{\text {forest bal }}\right)$ is of greater importance. After all, forests are essential in reducing the anthropogenic impact on the ecosystem. According to the data at the beginning of 2018, the forest cover of Ukraine (17.6\%) was significantly lower than in European countries. The average afforestation of the countries of Northern Europe is $46.8 \%$, Eastern Europe $-43.2 \%$, Western Europe $-24.2 \%$. Since forestation is mainly dependent on the climatic conditions, Ukrainian experts have determined for Ukraine the optimum forestry level of $20.0 \%$ [15], [17], [18].

As Ukraine is classified as a country with insufficient water supply, the indicator of water resources $\left(I_{\text {water_bal }}\right)$ is of the highest importance [19].

Each of the above components, in turn, is a combination of indicators with specific (different or identical) weighting factors. Thus, the first component is a half-sum of indicators characterizing the amount of humus in the soil $\left(I_{\text {gum }}\right)$ in percent and the introduction of mineral and organic fertilizers $\left(I_{\mathrm{af}}\right)$ also in tonnes per hectare.

$$
I_{\text {land_bal }}=0.5 I_{\text {gum }}+0.5 I_{\text {af }} \text {, }
$$


where

$$
I_{\mathrm{af}}=\frac{\mathrm{I}_{\text {miner }}+2 I_{\mathrm{org}}}{3} \text {. }
$$

In our opinion, the greater importance of the organic fertilizer application is because organic fertilizers contribute more to the increase of humus in the soil. Chemical fertilizers are used mainly to provide the desired $\mathrm{pH}$ level.

The second component is also a semi-sum of the indicators characterizing the areas of forest reproduction $\left(I_{\text {reprod }}\right)$ and the reduction of forest area due to harvesting and fires $\left(I_{\text {reduc }}\right)$.

$$
I_{\text {forest_bal }}=0.5 I_{\text {reduc }}+0.5 I_{\text {reprod }} \text {, }
$$

where

$$
I_{\text {reduc }}=0.3 I_{\text {harv }}+0.7 I_{\text {fires }} \text {. }
$$

The following assumptions explain the difference between the indicator's weight coefficients. Forest harvesting is a predominantly controlled process. The task of harvesting is not only the prevention of disease in the forest but also the income from the sale of timber. Fires are a natural disaster and, on the contrary, require additional costs for the organization of prevention and elimination of this phenomenon.

The third component is a semi-sum of the indicators characterizing the volume of reclaimed and reused water $\left(I_{\text {re_water }}\right)$ and the amount of water using from natural water bodies $\left(I_{\text {nut_water }}\right)$.

$$
I_{\text {water_bal }}=0.5 I_{\text {nat_water }}+0.5 I_{\text {re_water }}
$$

Used methodology makes it possible to compare the conservation status of the territories to identify the main problems of each region. However, such an assessment may not be sufficient motivation for the proactive action of regional leaders. It is also necessary to develop a regulatory forecast of the environmental status of the country and its territories, which reflects the desired characteristics.

The table of intermediate results illustrates that the worst situation with the balance of natural resources is in the Kherson region, where all indicators are below average. The position is slightly better in Luhansk, Odesa, Zaporizhzhya and Zhytomyr regions, which have four indicators below the average (out of six). Cherkasy, Chernihiv, Kharkiv, Mykolaiv, Poltava, Rivne, Sumy and Vinnytsya regions have twice the average districts for the average level by level. The ten oblasts have three indicators below the average. The Ivano-Frankivsk region has only one sub-indicator below the national average, but this does not mean that the area has the best balance of natural resources.

According to the calculations of the Environmental Management Indicator, four regions have a level below the national average. The last two places belong to Dnipropetrovsk and Donetsk regions. These areas are slightly higher than the average level of land balancing, but the high concentration of industrial enterprises that generate a lot of environmental emissions puts these regions in the position of outsiders. Despite the rather low level of environmental pollution (sixth place in the ranking), the worst among the regions of Ukraine the balance of natural resources puts the Kherson region in third place from the bottom by the level of the environmental management indicator. By balancing forest resources, the Lviv region was able to climb one place in the overall ranking compared to the ecological pollution rating. 
TABle 2. The Supplementary Results For CALCULATING THE BALANCE INDiCATOR FOR REGIONS OF UKRAINE

\begin{tabular}{lllllll}
\hline Region (Oblast) & $\boldsymbol{I}_{\text {gum }}$ & $\boldsymbol{I}_{\text {af }}$ & $\boldsymbol{I}_{\text {reduc }}$ & $\boldsymbol{I}_{\text {reprod }}$ & $\boldsymbol{I}_{\text {nat_water }}$ & $\boldsymbol{I}_{\text {re_water }}$ \\
\hline Cherkasy & 0.745 & 0.820 & 0.618 & 0.160 & 0.250 & 0.046 \\
Chernihiv & 0.586 & 0.656 & 0.652 & 0.398 & 0.429 & 0.014 \\
Chernivtsi & 0.633 & 0.042 & 0.708 & 0.168 & 0.682 & 0.393 \\
Dnipropetrovsk & 0.917 & 0.432 & 0.090 & 0.024 & 0.044 & 0.538 \\
Donetsk & 0.900 & 0.253 & 0.631 & 0.028 & 0.031 & 0.264 \\
Ivano-Frankivsk & 0.798 & 0.285 & 0.706 & 0.340 & 0.506 & 0.200 \\
Kharkiv & 0.998 & 0.528 & 0.565 & 0.098 & 0.167 & 0.066 \\
Kherson & 0.596 & 0.150 & 0.164 & 0.019 & 0.026 & 0.002 \\
Khmelnytskiy & 0.720 & 0.532 & 0.705 & 0.156 & 0.425 & 0.307 \\
Kirovohrad & 1.000 & 0.267 & 0.735 & 0.072 & 0.226 & 0.017 \\
Kyiv & 0.725 & 0.862 & 0.533 & 0.407 & 0.139 & 0.023 \\
Luhansk & 0.951 & 0.114 & 0.255 & 0.137 & 0.570 & 0.044 \\
Lviv & 0.650 & 0.204 & 0.682 & 0.362 & 0.256 & 0.056 \\
Mykolayiv & 0.788 & 0.222 & 0.690 & 0.016 & 0.182 & 0.389 \\
Odesa & 0.917 & 0.351 & 0.737 & 0.047 & 0.067 & 0.014 \\
Poltava & 0.774 & 0.929 & 0.615 & 0.149 & 0.363 & 0.096 \\
Rivne & 0.552 & 0.262 & 0.698 & 0.710 & 0.357 & 0.486 \\
Sumy & 0.852 & 0.487 & 0.663 & 0.176 & 0.479 & 0.008 \\
Ternopil & 0.762 & 0.379 & 0.725 & 0.062 & 0.918 & 0.005 \\
Vinnytsya & 0.657 & 0.614 & 0.710 & 0.203 & 0.381 & 0.311 \\
Volyn & 0.380 & 0.254 & 0.705 & 0.531 & 0.634 & 0.001 \\
Zakarpattya & 0.623 & 0.009 & 0.694 & 0.274 & 1.000 & 0.001 \\
Zaporizhzhya & 0.827 & 0.239 & 0.469 & 0.004 & 0.037 & 1.000 \\
Zhytomyr & 0.489 & 0.319 & 0.541 & 1.000 & 0.409 & 0.019 \\
\hline Average & 0.743 & 0.384 & 0.562 & 0.223 & 0.122 & 0.174 \\
\hline Dan & & & & &
\end{tabular}

Data calculated from [15], [16], [20], [21]

TABLE 3. THE VALUE of A COMMON INDICATOR OF ACHIEVEMENT IN ENVIRONMENTAL MANAGEMENT

\begin{tabular}{llllllll}
\hline Region (Oblast) & $\boldsymbol{I}_{\text {land_bal }}$ & $\boldsymbol{I}_{\text {forest_bal }}$ & $\boldsymbol{I}_{\text {water_bal }}$ & $\boldsymbol{I}_{\text {balance }}$ & $\boldsymbol{I}_{\text {pollut }}$ & $\boldsymbol{I}$ EMP & Rating \\
\hline Chernivtsi & 0.337 & 0.438 & 0.536 & 0.452 & 0.989 & 0.720 & 1 \\
Zakarpattya & 0.316 & 0.484 & 0.500 & 0.449 & 0.629 & 0.539 & 2 \\
Rivne & 0.407 & 0.704 & 0.421 & 0.517 & 0.462 & 0.490 & 3 \\
Volyn & 0.317 & 0.618 & 0.317 & 0.422 & 0.533 & 0.477 & 4 \\
Zhytomyr & 0.404 & 0.771 & 0.214 & 0.456 & 0.431 & 0.444 & 5 \\
Ternopil & 0.570 & 0.393 & 0.461 & 0.465 & 0.391 & 0.428 & 6 \\
Vinnytsya & 0.635 & 0.457 & 0.346 & 0.457 & 0.362 & 0.410 & 7 \\
Khmelnytskiy & 0.626 & 0.431 & 0.365 & 0.453 & 0.356 & 0.405 & 8 \\
Chernihiv & 0.621 & 0.525 & 0.221 & 0.427 & 0.373 & 0.400 & 9 \\
Cherkasy & 0.782 & 0.389 & 0.147 & 0.391 & 0.382 & 0.386 & 10 \\
Ivano-Frankivsk & 0.542 & 0.523 & 0.352 & 0.459 & 0.310 & 0.384 & 11 \\
Poltava & 0.852 & 0.382 & 0.229 & 0.438 & 0.316 & 0.377 & 12 \\
Sumy & 0.669 & 0.419 & 0.243 & 0.411 & 0.323 & 0.367 & 13 \\
Kirovohrad & 0.634 & 0.403 & 0.121 & 0.348 & 0.384 & 0.366 & 14 \\
\hline
\end{tabular}




\begin{tabular}{llllllll}
\hline Kyiv & & & & & & & \\
Mykolayiv & 0.794 & 0.470 & 0.081 & 0.395 & 0.323 & 0.359 & 15 \\
Kharkiv & 0.505 & 0.353 & 0.285 & 0.364 & 0.347 & 0.355 & 16 \\
Zaporizhzhya & 0.763 & 0.331 & 0.116 & 0.353 & 0.312 & 0.332 & 17 \\
Odesa & 0.533 & 0.236 & 0.518 & 0.423 & 0.240 & 0.332 & 18 \\
Luhansk & 0.634 & 0.392 & 0.040 & 0.312 & 0.313 & 0.312 & 19 \\
Lviv & 0.533 & 0.196 & 0.307 & 0.325 & 0.300 & 0.312 & 20 \\
Kherson & 0.427 & 0.522 & 0.140 & 0.345 & 0.249 & 0.297 & 21 \\
Donetsk & 0.373 & 0.092 & 0.014 & 0.131 & 0.400 & 0.266 & 22 \\
Dnipropetrovsk & 0.577 & 0.330 & 0.147 & 0.318 & 0.090 & 0.204 & 23 \\
\hline Average & 0.675 & 0.057 & 0.291 & 0.305 & 0.059 & 0.182 & 24 \\
\hline
\end{tabular}

Benchmarking comparisons of indicators for Ukraine and European countries, as well as optimal sound indicators for the regions, should be the marks for determining the regulatory level of indicators. International comparisons take precedence in substantiating the regulatory forecast for Ukraine.

For its regions, it is advisable to form a normative level based on the results of scientific research, the necessary calculations. For example, the need for fertilizer depends on cultivated crops, crop rotation, pre-depletion of land. The number of fertilizers provided in the regulatory forecast should be sufficient not only to ensure a zero balance but also to restore the lost soil quality indicators. Experts justify optimal forest cover for the regions of Ukraine. Particular attention needs to be given to justifying the balance of water resources. After all, according to the UNESCO classification, Ukraine is classified as a country with low water supply. At the same time, the water capacity of the produced national product in Ukraine is 4-10 times higher than in Germany, Japan, France, the USA [22].

\section{USing Strategic EnVIronmental ASSESSMENT OF TERritory in Public Administration for Local DeVelopment}

The assessments results of achievements in the environmental management of territories provide a comparative description of the state of ecological protection of habitats, help to identify the main problems of each region and national environmental issues.

For ensuring positive changes in environmental management, it is necessary to provide a systematic assessment of threats posed not only by the implementation of long-term projects but also current activities, justification of ways to overcome them, development of necessary measures for state regulation. Therefore, strategic environmental assessment should be conducted not only at the stage of consideration of draft plans and programs for long-term development but also in the current activities. It should become a component of strategic thinking not only of civil servants but also of socially responsible entrepreneurs. After all, the recent decisions on the selection of crop areas, compliance with scientifically sound crop rotations have long-term consequences not only for agriculture but also for the population, tourism, water resources.

In the southern regions of Ukraine, especially in the Kherson oblast, there are contradictions between the development of agriculture and the tourism industry. Agriculture is directly linked to the use of natural resources and has a significant impact on the environment, recreational resources and public health. Thus, one of the most valuable food crops, which is a staple food for almost half of humanity, is widely used as a dietary product, according to 
Rice. The value of this plant is also that the accompanying crop products are of great importance, and its cultivation can be carried out on low-yielding, saline lands, in specially equipped flooded areas. Analytical studies of experts show that the costs of building rice irrigation systems (RIS) pay off quickly, and the yield of this crop is 8-10 per cent higher than winter and spring cereals [23]. The adverse effects of the development of rice growing are also very significant. Large doses of fertilizers adversely affect soil quality, reduce humus content. Flooding allows the soil to be washed away, but the groundwater mineralization increases by 5-10 times. Salt and other components of the soil medium are also removed during the discharge of drainage waters of the RIS. During the year, 25-30 tonnes of salts are washed from each hectare [24].

However, not only rice growing but also the development of irrigation agriculture, in general, creates problems for the population. This process is since it is accompanied by an increase in the vulnerability of land to flooding due to the slowdown of the interaction of surface and groundwater with excessive regulation of the river network (especially the Dnieper River).

The impact of the agro-industrial complex on both water and land resources depends on its structure. Between 2000 and 2017, agricultural output (at comparative prices in 2010) increased by $65.0 \%$. At the same time, livestock production increased by $28.0 \%$ and crop production increased by $72.0 \%$. As a result, crop production accounts for $93.0 \%$ of agricultural output. There are also significant changes in the structure of the acreage. In 1990, $37.0 \%$ of the area under cultivation was forage crops, technical only $11.6 \%$. In 2010 , the share of the forage area of forage crops decreased to $9.6 \%$, and industrial - increased to $27.1 \%$. This trend continued in the following years. In 2017, the share of forage crops fell to $6.7 \%$, of industrial plants to $33.6 \%$ [25].

Industrial crops are commercially attractive. Therefore, tenants give them an advantage, neglect the requirements of crop rotation, rational structure of plants. Experts believe that this leads to the depletion of the earth, a catastrophic decline in its fertility. The safe share of sunflower in crops can't exceed $10 \%$, because it can be returned to the same field only in 8 10 years. However, the percentage of acreage occupied by sunflower was $5.0 \%$ in 1990 and $21.9 \%$ in 2017 [25]-[27].

Strategic environmental assessment should be the basis for the development of the territory development strategy and its ecological balance. A promising ecological balance needs to be developed in conjunction with strategic plans, as it should consider the statistical evaluation of the dynamics of indicators while maintaining the current trends, the results of the crop rotation cycle, the implementation of long-term projects to improve the environmental situation. Along with this, it is advisable to make calculations to adjust the annual ecological balance, taking into account the structure of acreage, the expected yield of crops, changes in the contamination of the territory due to the introduction of innovative technologies in the production of products and corrective actions in nature conservation activities.

The dynamics of environmental pollution indicators by statistical methods are described with low confidence due to their significant fluctuations. Therefore, it is only possible to map the level of metrics over a period of time. For example, emissions of harmful substances into the air from stationary sources of pollution in the period from 1995 to 2010 decreased by almost 2.3 times. And in 2017 they were 1.6 times lower than in 2010. Contaminated water discharged into natural surface water in 2000 was 3313 million $\mathrm{m}^{3}$, in $2010-1744$, and in 2017 - 997 million $\mathrm{m}^{3}$. Waste of I-III hazard classes was generated in $2000-2613.2$ thousand tonnes, in 2010 - 1659.8 thousand tonnes, in 2017 - 605.3 thousand tonnes [20], [27]. That is, there are definite trends in change. 
The dynamics of indicators characterizing the depletion and restoration of land resources is negative. The productivity of farmland depends on the humus content. The Ukrainian black soil was considered to be the most fertile. At L. Pasteur Institute in Paris, a sample of Ukrainian black soil with a humus content of 10.0-12.0\% is stored. However, in tilled farmland, the humus content is much lower and gradually lost. Currently, it is only $2.5-4.2 \%$. Over the last five years, the humus content has decreased by $0.3 \%$ [21]. For a natural recovery of losses of $0.3 \%$ requires ten years of 'rest' soil from crops or the introduction of a significant amount of fertilizers. Ukrainian experts have justified the maximum allowable humus losses and the corresponding levels of environmental safety. The losses from $0.91 \%$ to $1.35 \%$ of humus are ecologically dangerous and more than $1.35 \%$ are critical. They also note that over the last 100 years, the humus content in soils has already decreased by $1.16 \%$, which corresponds to the environmental level. If current trends are maintained, soil fertility can reach a critical state in 20-30 years [28].

Mineral and organic fertilizers are required to improve soil condition. In 1990, mineral fertilizers in nutrients, $141 \mathrm{~kg}$ and 8.6 tonnes of organic fertilizers per 1 ha of acreage were introduced. In 2000 , these figures decreased in accordance with $13.0 \mathrm{~kg}$ of mineral fertilizers and 1.3 tonnes of organic fertilizers per 1 ha of acreage. In the following years, the situation with the introduction of mineral fertilizers improved slightly, and with organic fertilizers, it became even worse. Since 2010, only 0.5 tonnes per ha have been introduced [25], [26]. Below are the trend equations that describe these trends.

$$
\begin{gathered}
Y_{\mathrm{m}}=5.263 t+4.222, \\
Y_{\mathrm{o}}=0.005 t^{2}-5.263 t+1.2279,
\end{gathered}
$$

where

$Y_{\mathrm{m}} \quad$ applying mineral fertilizers;

$Y_{\mathrm{o}} \quad$ applying organic fertilizers;

$t \quad$ serial number of the time period $(2000=1$, etc. $)$

The values of the approximation reliability $R_{Y_{\mathrm{m}}}^{2}=0.9692$ and $R_{Y_{\mathrm{o}}}^{2}=0.9585$ show a high degree of correspondence of the trend models with the original data.

The estimated values for 2023 are $125 \mathrm{~kg}$ of mineral fertilizers and 1 ton of organic fertilizers per 1 ha of acreage. It is catastrophically small. At least 10-12 t/ha of organic fertilizers in the steppe zone, 11-13 t/ha on irrigation lands, 13-15 t/ha standard for the Forest-steppe, 18-20 t/ha for the Polissya region (extremely moist, wooded and wetland) must be applied annually to compensate for humus losses [29].

However, the ability to make enough organic fertilizers depends on the development of animal husbandry, which is the leading supplier of manure. At the same time, almost $70 \%$ of the slurry is derived from cattle. The population in 1990 was 24623.4 thousand. In 2017 , the headcount dropped to 3530,8 thousand (nearly seven times) [25], [26]. The trend of livestock changes since 2000 can be described by the following equation:

$$
Y_{\text {stock }}=23.025 t^{2}-792.9 t+110590,
$$

where $Y_{\text {stock }}$ is the number of cattle (thousand heads). 
The magnitude of the approximation reliability $R_{Y_{\text {sook }}}^{2}=0.9768$ indicates a high degree of model fit to the original data.

With the current trend, the number of livestock can be expected to increase to 4533.5 thousand stocks in 2023, which is not only sufficient to restore lost fertility but also to prevent further losses. Therefore, the development of agriculture requires state regulation, as current trends have a negative impact not only on the environment but also on food security and public health.

If current environmental management trends persist, there is a threat of deforestation, especially in the southern regions.

The general trend for forest restoration in Ukraine is characterized by the following trend Eq. (15):

$$
Y_{\text {forest renov }}=0.0088 t^{4}-0.3258 t^{3}+3.5729 t^{2}-8.8487 t+45.705 \text {, }
$$

where $Y_{\text {forest renov }}-$ annual index reproduction of forests, thousand ha.

The magnitude of the approximation reliability $R_{Y_{\text {s }}}^{2}=0.9465$ indicates a high degree of model fit to the original data.

Given the fact that the actual forest cover is lower than the optimum, it is advisable not only to compensate for the loss annually but also to increase the area of forests. Between 2000 and 2009 , there was an increase in the field of reclaimed timbers (from 37.8 thousand hectares to 80.9 thousand hectares) [30]. But since 2010, there has been a significant reduction in forest reproduction. It is estimated that by 2023 it will reach only 24.6 thousand hectares. Even worse is the situation in the southern regions affected by heat and forest fires. The situation in the Kherson region is especially threatening. On its territory is the largest desert in Europe. Many years ago, coniferous forests were artificially created on the sand band. In recent years, they have declined significantly as a result of fires. Between 2000 and 2008, the area of annual forest reproduction increased from 185 ha to 5538 ha [20]. This partially offset the loss of 2007 from a fire that destroyed 8886 hectares of forest. But in the following years, the remedial action weakened. Although fires reduced the area of wood in 2012 by 2493 hectares, 2014 - by 756 hectares, 2017 - 1137 hectares. Forest recovery in 2017 was only 223 hectares [20]. The trend equation describing the recession period in the Kherson region for forest restoration will look like:

$$
Y_{\text {forestrenov_Kherson }}=225.37 t+2360.2 ; R^{2}=0.9795 \text {. }
$$

Consequently, if this trend continues in 2020, the recovery will come to nought. Therefore, it is necessary to improve state regulation of forest protection measures, prevention and timely detection of fires, proposals for their extinguishing and provision of new plantations to prevent further conversion of the territory to the desert.

Water quality depends on the quality of life of the population, the possibility of development of agriculture and industry. The structure of water consumption depends on the population, the development of industry and agriculture. In OECD countries, the share of clean water consumption in the industrial complex does not exceed $10.0 \%$, in agriculture, it is $74.0 \%$, in the domestic sector $-16.0 \%$. In Ukraine, the largest share of water is consumed by industry $(48.0 \%$ ), agriculture accounts for $30.0 \%$, households $-22.0 \%$ [30]. 
There are positive trends in the use of water resources in Ukraine (a decrease in the volume of freshwater using and, consequently, an increase in the share of return water using), which is reflected by the following trends:

$$
Y_{\mathrm{fw}}=0.0896 t^{5}-4.0151 t^{4}+58.668 t^{3}-289.67 t^{2}-147.17 t+13312 ; R^{2}=0.925,
$$

where $Y_{\mathrm{fw}}$ - using of fresh water, $\mathrm{mln} . \mathrm{m}^{3}$.

$$
Y_{\mathrm{rw}}=0.1041 t^{6}-6.2732 t^{5}+145.97 t^{4}-1638.6 t^{2}-20028 t-57883 ; R^{2}=0.794,
$$

where $Y_{\mathrm{fw}}-$ using of return water, $\mathrm{mln} . \mathrm{m}^{3}$.

In Ukraine, according to statistics and projected estimates, in 2000, freshwater was used in the quantity of 12991 million $\mathrm{m}^{3}$, in 2017 - only 6853 million $\mathrm{m}^{3}$, the estimated amount for $2023-6274$ million $\mathrm{m}^{3}$. The volume of circulating and re-sequential water supply also slightly decreases from 41523 million $\mathrm{m}^{3}$ in 2000 to 38716 million $\mathrm{m}^{3}$ in 2017, the forecast amount for 2023 is 27563 million $\mathrm{m}^{3}$ (See Fig. 3). But the share of this water in the total use for industrial purposes increases to $90 \%$.

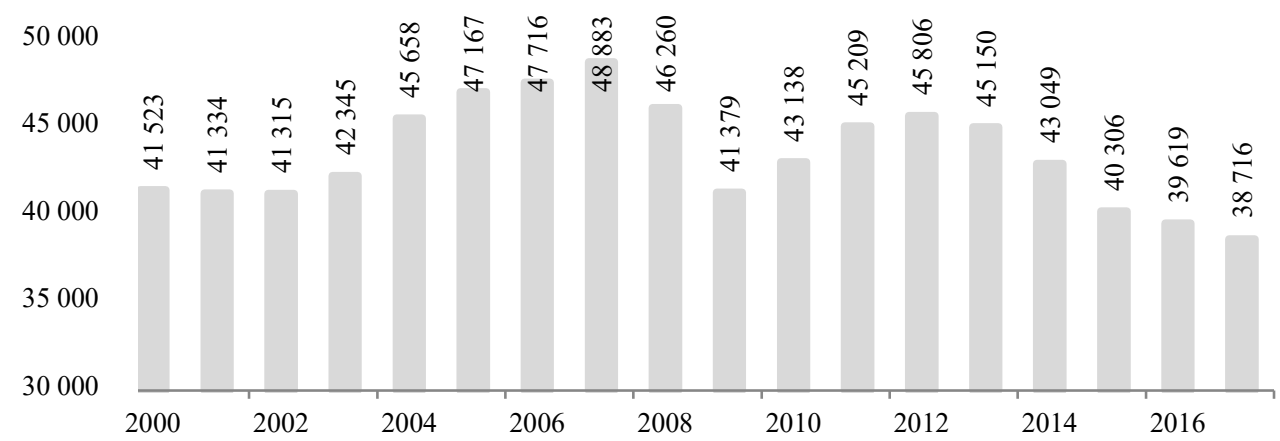

Fig. 3. Using of return water, $\mathrm{mln} . \mathrm{m}^{3}$.

However, such positive developments do not reduce the urgency of finding ways to use water more efficiently, especially in agricultural production.

For preventing further pollution of the territories and the irrational use of natural resources, state regulation of the processes of a fundamental restructuring of agricultural and industrial production of regions is necessary, taking into account the ecological status and environmental impact of the components of their economic complexes.

The location of the rice harvesting zone on the territory of the recreational resources of the southern regions of Ukraine, the pollution of the wastewaters of the Black and Azov seas requires the development of a system of regulatory measures, improvement of the technology of rice cultivation. The experience of the world, rice producers, including Japan, China, USA shows that rice crop rotations are mainly located in recreational areas, and intensive technologies are used in $80 \%$ of the rice-growing regions. But the contradiction is eliminated due to strict requirements for landowners, technologies and technical condition of RIS [24]. Considering the consumer value and profitability of rice should be necessary to determine the scientifically valid share of it in the structure of acreage and to introduce technologies 
developed by scientists that reduce environmental damage and allow to obtain environmentally friendly products.

The results of the researchers who proved the effectiveness of using drip irrigation instead of rice checks in the south of Ukraine are encouraging. This will allow the cultivation of rice in field crop rotations, reduce freshwater costs and negative impact on the soil as a result of systematic flooding, prevent technical discharges of water and pollution of reservoirs.

The production of different crops should be balanced concerning their impact on soil fertility, water use and expert advice on rational crop rotation. For example, in comparison with other plants, sunflower extracts the highest amount of nutrients from the soil. On 1 centre of sunflower crop nitrogen losses are more significant than in winter wheat, corn on grain and rice almost two times, perennial grasses - four times, cabbage - twenty times; phosphorus, respectively, two and a half, five and twenty times. The losses of potassium on sunflower cultivation in comparison with rice and corn are higher four times, wheat - eight times, perennial herbs - ten times, cabbage - forty times. Most of the water during the growing season is consumed when growing rice - by 1 ha - up to $20000 \mathrm{~m}^{3}$, cabbage $-8000 \mathrm{~m}^{3}$, corn $-3000 \mathrm{~m}^{3}$ [31], [32].

Adherence to a rational structure of agricultural production, scientifically sound crop rotation should be motivated. To this end, environmental taxation is widely used in the world. In 2011, Ukraine also put in place ecological tax instead of fees for the use of natural resources and pollution. According to the Budget Code of Ukraine, revenues from environmental tax in terms of carbon dioxide emissions are credited to the general budget of the state budget of 100 per cent, while revenues from emissions of other pollutants are credited to the general fund of the state budget only in the amount of 45 per cent. The other 55 per cent of ecological tax goes to the special fund of local budgets, including: 25 per cent to rural, settlement, city budgets, budgets of the united territorial communities, which are created in accordance with the law and perspective plan of formation of territories of communities; 30 per cent to regional budgets and the budget of the Autonomous Republic of Crimea. Budgets of cities of Kyiv and Sevastopol get 55 per cent of ecological tax [33].

However, the effectiveness of environmental taxes depends on their incentive action and targeted use. To improve the ecological situation, an effective system of economic incentives and sanctions should be put in place, taking into account global experience.

\section{Conclusions}

Based on the above, the following conclusions can be drawn.

For achieving positive changes in the management of sustainable development of territories, it is necessary to increase the effectiveness of state regulation based on the systematic application of strategic environmental assessment. Schemes of using SEA in the system of ensuring sustainable, balanced development of the territory and development of ecological balance are given.

For identifying regional weaknesses in the management of the environment is facilitated by assessing the environmental component of the indicator of their sustainable development. An illustration of the feasibility of the proposed evaluation methodology is the calculations performed for all regions of Ukraine.

Approaches to forecasting indicators based on which assessed the environmental component of sustainable development are demonstrated. In particular, it was found that in 
Ukraine, there are positive trends only in the use of water resources. Therefore, if the current trends persist, there is a threat of further decline in soil fertility and forest cover.

In the process of substantiation of indicators of the desired state of the environment, in addition to optimistic forecasting, normative forecasts should be used. Therefore, in the system of ecological management, strategic environmental assessment and development of ecological balance are tools for identifying ways to bring the real state of the environment closer to the normative one. It is necessary to improve the financial and economical methods of public regulation of agricultural development, in particular, to stimulate the growth of animal husbandry and rational use of nature. The reasonable using of nature implies the balanced development of the commercial complex of the region, taking into account the environmental impact of its components. In particular, special attention is needed to the structure of the acreage, which significantly affects the fertility of soils and the state of recreational resources.

Local authorities should be empowered to regulate the environmental payments that remain at their disposal, to use measures to influence the structure of the economic complex, to introduce innovative technologies that have a positive impact on the environmental status of the environment.

It is expedient to assess the effectiveness of government at all levels in the management of the environment condition by comparing the real achievements of environmental indicators with the normative ones (established as the desired result at a particular stage of development).

\section{REFERENCES}

[1] Our Common Future. Report of the World Commission on Environment and Development [Online]. [Accessed 12.12.2019]. Available: https://sustainabledevelopment.un.org/content/documents/5987our-common-future.pdf

[2] Lucchetti M. G., et al. The Role of Environmental Evaluation within Circular Economy: An Application of Life Cycle Assessment (LCA) Method in the Detergents Sector. Environmental and Climate Technologies 2019:23(2):238-257. https://doi.org/10.2478/rtuect-2019-0066

[3] Indzere Z., et al. The Evaluation of Factors Affecting Bioeconomy Development Using Transdisciplinary Approach. Environmental and Climate Technologies 2019:23(3):360-369. https://doi.org/10.2478/rtuect-2019-0101

[4] Muizniece I., et al. Circular Economy and Bioeconomy Interaction Development as Future for Rural Regions. Case Study of Aizkraukle Region in Latvia. Environmental and Climate Technologies 2019:23(3):129-146. https://doi.org/10.2478/rtuect-2019-0084

[5] Directive 2001/42/EC of the European Parliament and of the Council of 27 June 2001 on the assessment of the effects of certain plans and programmes on the environment. Official Journal of the European Union 2001:L 197.

[6] Fundingsland Tetlow M., Hanusch M. Strategic environmental assessment; the state of the art. Impact Assessment and Project Appraisal 2012:30(1):15-24. https://doi.org/10.1080/14615517.2012.666400

[7] De Montis A., Ledda A., Caschili S. Overcoming implementation barriers: A method for designing Strategic Environmental Assessment guidelines. Environmental Impact Assessment Review 2016:61:78-87. https://doi.org/10.1016/j.eiar.2016.07.006

[8] Pro ratifikacijju Protokolu pro strategichnu ocinku do Konvencii pro ocinku vplivu na navkolishne seredovische $\mathrm{u}$ transkordonnomu konteksti (On the ratification of the Protocol on Strategic Environmental Assessment to the Convention on Environmental Impact Assessment in a Transboundary Context: Law of Ukraine No 562-VIII of 01.07.2015.). Vidomosti Virhovnoy Radi 2015:32:319. (in Ukrainian)

[9] Pro strategichnu ekologichnu ocinku (Strategic Environmental Assessment: Law of Ukraine No2354-VIII of 20.03.2018.). Vidomosti Virhovnoy Radi 2018:16:138. (in Ukrainian)

[10] Sadler B. Handbook of strategic environmental assessment. London: Earthscan, 2011. https://doi.org/10.4324/9781849775434

[11] Opriljudneno Zvit pro Strategichnu Ekologichnu Ocinku Regionaljnoj Strategii Rozvitku Zakarpatsjkoi Oblasti na Period 2021-2027 Rokiv (Strategic Environmental Assessment Report of the Transcarpathian Regional Development Strategy for the period 2021 - 2027.). Uzhhorod: ZODA, 2019. (in Ukrainian) 
[12] Zvit Pro Strategichnu Ekologichnu Ocinku Strategii Rozvitku Mosta Gorishni do 2028 Roku (Report on the Strategic Environmental Assessment of the Horyshni Plavni Development Strategy until 2028) [Online]. [Accessed 20.12.2019]. Available: https://ua.boell.org/sites/default/files/uploads/2017/11/zvit_seo_gorishni_plavni_ukr.pdf_(in Ukrainian)

[13] Ministry of Energy. Povidomlennja pro opriljudnennja Zvitu pro strategichnu ekologichnu ocinku (Communication on the release of the Strategic Environmental Assessment Report. Ministry of Energy and Environmental Protection of Ukraine.). Kyiv: Ministry of Energy, 2019. (in Ukrainian)

[14] Strategic Environmental Assessment (SEA): Overview - Legal Context [Online]. [Accessed 18.12.2019]. Available: https://ec.europa.eu/environment/eia/sea-legalcontext.htm

[15] Statistichnij Zbirnik Regioni Ukraini 2018, Chastina I (Regions of Ukraine 2018 Part I, Statistical publication.) Kyiv: State Statistics Service of Ukraine, 2018.

[16] Statistichnij Zbirnik Regioni Ukraini 2018, Chastina II (Regions of Ukraine 2018 Part II, Statistical publication.) Kyiv: State Statistics Service of Ukraine, 2018.

[17] Eurostat. European Commission [Online]. [Accessed 25.12.2019]. Available: https://ec.europa.eu/eurostat/data/database

[18] Tkach V. Lisi ta Lisististj v Ukraini: Suchasnij Stan i Perspektivi Rozvitku (Forests and forest cover of Ukraine: the current state and perspectives of development.) Ukrainian Geographical Journal 2012:2:49-55. (in Ukrainian)

[19] Ukraine Country Note. The Danube Water Program. Vienna: IAWD, 2015.

[20] Statistichnij Zbirnik Dovkillja Ukraini za 2018 rik (Statistical Yearbook Environment of Ukraine 2018.) Kyiv: State Statistics Service of Ukraine, 2019.

[21] Yacuk I. P., et al. Naukovi Doslidzhennja z Monitoringu ta Obstezhennja Siljsjkogospodarsjkih Ugidj Ukraini za rezuljtatami X turu (Scientific research on monitoring and survey of agricultural lands on the results of the 10th round.) Kyiv: State Institution 'Soils Protection Institute of Ukraine', 2018.

[22] Water productivity. The World Bank Data [Online]. [Accessed 18.12.2019]. Available: https://data.worldbank.org/indicator/ER.GDP.FWTL.M3.KD

[23] Vitrati na Virobnictvo Produkcii Ciljsjkogo Gospodarstva v Siljsjkogospodarsjkih Pidpriemstvah za 2016 rik (Expenditure on the production of agricultural products in agricultural enterprises for 2016. Kyiv: State Statistics Service of Ukraine, 2017.

[24] Global Rice Science Partnership. Rice almanac. Source Book for One of the Most Important Economic Activities on Earth. 4th edition. Los Baños: International Rice Research Institute, 2013.

[25] Statistichnij Zbirnik 2018 (Agriculture of Ukraine. The Statistical Yearbook for 2018). Kyiv: State Statistics Service of Ukraine, 2019.

[26] Statistichnij Zbirnik 2010 (Agriculture of Ukraine. The Statistical Yearbook for 2010). Kyiv: State Statistics Service of Ukraine, 2011.

[27] Popova O. Stalij rozvitok agrosferi Ukraini: politika I mehanizmi (Sustainable Development of Ukraine's Agrosphere: Policy and Mechanisms.). Kyiv: Institute of the Economy and Forecasting of the National Academy of Sciences of Ukraine, 2009. (in Ukrainian)

[28] Budzyak O., Budzyak V. Issues of the management of ecologically safe land use. Agrosvit 2017:5:3-9.

[29] Rossokha V., Pronko L. Agroenergetichnij potencial zemli v konteksti ekologichnoi bezpeki (Agroenergetical land potential in the environmental safety context.). Economics. Finances. Management: topical issues of science and practice 2016:10:37-48.

[30] Annual freshwater withdrawals. The World Bank Data [Online]. [Accessed 18.12.2019]. Available: https://data.worldbank.org/indicator/

[31] Zosj-Kior M. Udoskonalennja sistemi upravlinnja zemeljnimi resursami agrarnih pidpriemstv v umovah globalizacii (Improvement of the land management system of agricultural enterprises in the conditions of globalization.) Poltava: NTU, 2015. (in Ukrainian)

[32] Crop Water Needs [Online]. [Accessed 17.12.2019]. Available: http://www.fao.org/3/s2022e/s2022e07.htm

[33] Pro administruvannya ekologichnogo podatku. List DFS ukrayini vid (About administering the ecological tax. Letter SFS of Ukraine from 16.01.2019 No 1422/7/99-99-12-03-04-17. Visnik. Oficijno pro Podatki 2019. 